\title{
The effect of employee's humor training on depression, anxiety and stress of the elderly residents in Tehran's nursing homes: a randomized clinical trial
}

\author{
Tannaz Taheri Gharagzlu ${ }^{1}$, Mahboubeh Safavi ${ }^{2}$, Mohammad Fesharaki ${ }^{3}$ \\ ${ }^{1}$ MSc in Psychiatric Nursing, Faculty of Nursing and Midwifery, Tehran Medical Sciences, Islamic Azad University, \\ Tehran, Iran \\ ${ }^{2}$ Assistant Professor, PhD in Health Services Management, Faculty of Nursing and Midwifery, Tehran Medical \\ Sciences, Islamic Azad University, Tehran, Iran \\ ${ }^{3}$ Associate Professor, PhD in Biostatistics, Faculty of Nursing and Midwifery, Tehran Medical Sciences, Islamic Azad \\ University, Tehran, Iran
}

\begin{abstract}
Background: Nowadays, elderly has a high prevalence and older people face psychological problems. Educational interventions of nursing homes`staff can affect their satisfaction and performance. In this study, the effect of employees' humorous intervention on depression, anxiety and stress among elderly residents in selected nursing homes in Tehran was investigated in 2018.

Materials and methods: This randomized clinical trial study was performed on two groups of 30 elderly people in Tohid (intervention) and Farzanegan (control) nursing homes. The staff of the Tohid center received the training of humor in 7 sessions of 90 minutes. Demographic questionnaire and Depression, Anxiety and Stress Questionnaire (DASS-21) were used for data gathering. Data analysis was performed using SPSS-v23.

Results: The two groups did not differ significantly in terms of demographic variables and depression, anxiety, and stress in the pretest stage $(\mathrm{p}>0.05)$. In the intervention group, there was a significant decrease in anxiety and stress in the elderly $(p<0.05)$. The results of covariance analysis indicated the efficacy of intervention in reducing anxiety and stress, so that $43 \%$ of variation of anxiety and $25 \%$ of variation of stress were due to independent variable.

Conclusion: According to our findings, staff humor training is effective in reducing the anxiety and stress of the elderly. Because of its low cost, its capability and safety, it is recommended that the conditions for using this intervention are provided in the nursing homes.
\end{abstract}

Keywords: Humor, Depression, Anxiety, Stress, Elderly, Nursing home.

Cited as: Taheri Gharagzlu T, Safavi M, Fesharaki M. The effect of employee's humor training on depression, anxiety and stress of the elderly residents in Tehran's nursing homes: a randomized clinical trial. Medical Science Journal of Islamic Azad University, Tehran Medical Branch 2020; 30(3): 287-298.

Correspondence to: Mahboubeh Safavi

Tel: +989125543502

E-mail: msafavi@iautmu.ac.ir

ORCID ID: 0000-0001-8274-6049

Received: 19 Apr 2019 Accepted: 23 Jul 2019 
مجله علوم يزشكى دانشَاه آزاد اسلامى

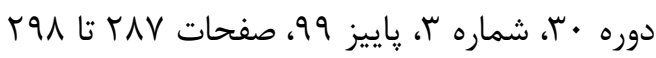

Original

Article

\section{تاثير مداخله آموزش شوخ طبعى كاركنان بر افسردكى، اضطراب و استرس سالمندان ساكن در آسايشگاههاى شهر تهران: يك كار آزمايى بالينى تصادفى شده}

\section{طناز طاهرى قراكزلو'، محبوبه صفوى"، محمد فشاركى"}

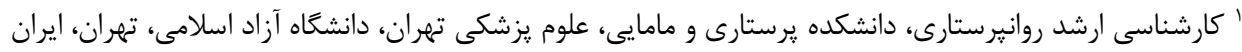

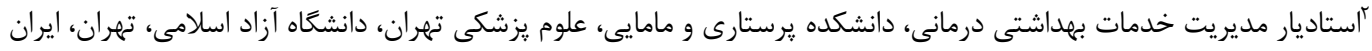

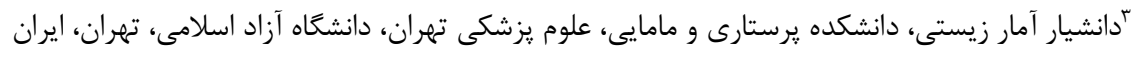
جكيده

سابقه و هدف: /مروزه سالمندى شيوع بالايى دارد و سالمندان با مشكلات روانشناختى مواجه هستند. مداخلات آموزشى كاركنان

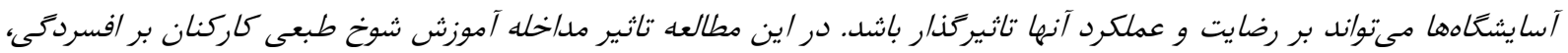

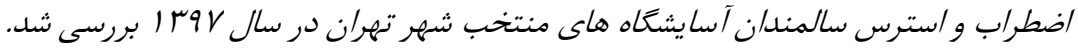

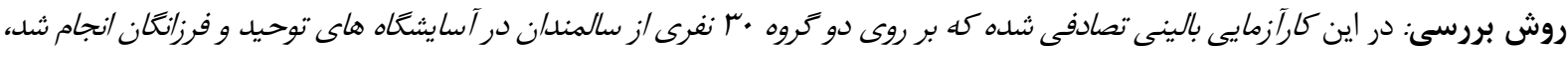

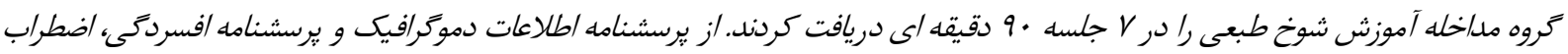

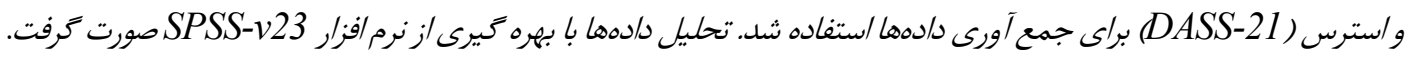

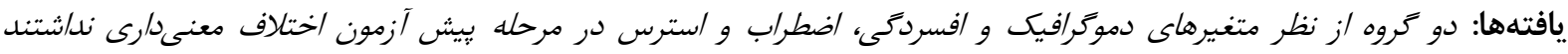

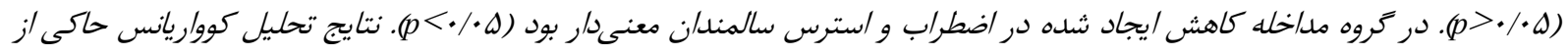

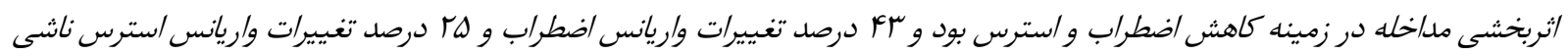
از متغير مستقل بود. نتيجهَيرى: براساس نتايج مطالعه حاضر، مداخله آموزش شوخ طبعى كاركنان در زمينه كاهش اضطراب و استرس سالمندان موثر است و لذا با توجه به كمر هزينه بودن، قابليت اجراييى و/يمن بودن، توصيه مى شود شرايط براى اجراى آن در ساير آسا يشعاهها فراهم شود.

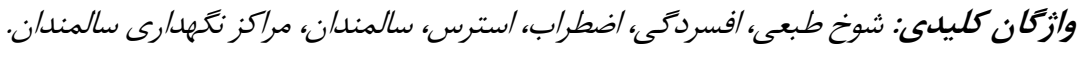

جمعيت را به خود اختصاص دهند، آن جامعه سالمند تلقى مقدمه

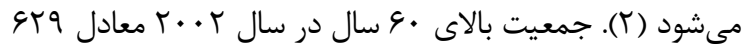
ميليون نفر (•ا درصد كل جمعيت جهان) بود كه بر اساس برآوردها در سال •ه •r به r ميليارد نفر (·r درصد) خواهد رسيد (r-D). كشورهاى در حال توسعه كه سهرم بيشترى از جمعيت دنيا را در خود جاى دادهاند، بيشتر با سالمندى جمعيت مواجه هستند، به زونهاى كه .9 درصد از سالمندان جهان در كشورهاى در حال توسعه زندگى مى كنند (9). ايران نيز در روند سالمندى جمعيت قرار گرفته است. پيش بيش بينى

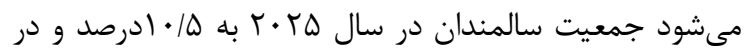

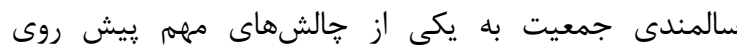
نظامهاى سلامت در دنيا تبديل شده است. سازمان بهدئ بهاشت

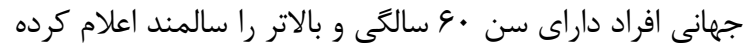

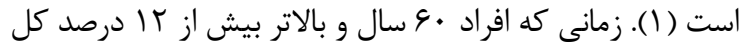

آدرس نويسنده مسئول: تهر ان، دانشكده يرستارى و مامايى، علوم بزشكى تهـران، دانشـكاه آزاد اسـلامى،

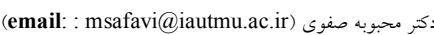
ORCID ID: 0000-0001-8274-6049

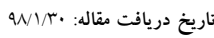
تاريخ خذيرش مقاله: هN/D/1 
انجمن روانيزشكان آمريكا درصد بالايى از مبتلايان به

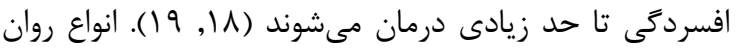

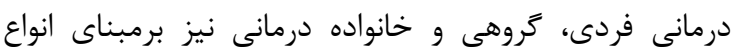

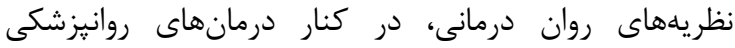

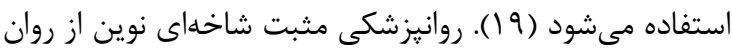

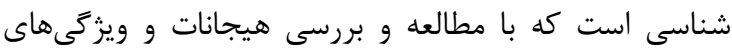
مثبت شخصيتى به جنبههاى خوش بينانهترى همجون سلامت روانى، شادى، خنده، شوخى و شوخ طبعى مي ير يردازد. از بين تمام مباحث مورد بررسى در روان شناسى مثبت، شايد يكى از جالبترين و در عين حال جديدترين آنها شوخ طبعى دمانى

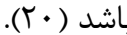

بى شك هر يك از انسانها در طول زندكى روزمره خويش در شرايطى قرار مى كيرند كه ممكن است كنترل اعصاب و رفتار إنار

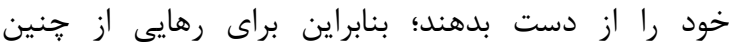

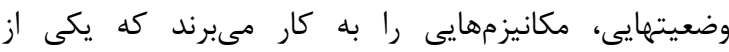

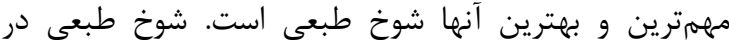
ارتقاء سلامت روانى و جسمانى افراد نيز نقش مهردئ إنى ايفا

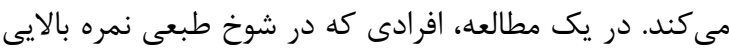
كسب كرده بودند، تنش كمترى را نيز تجربه كرده و اين مطالعه نشان داد كه رابطه منفى بين شوخى و سطح اضطراب

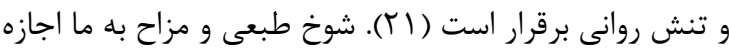
مىدهد ترسها و ديكر احساسات منفى خود را بدون ايجاد

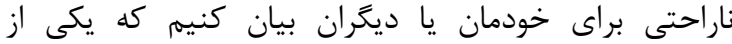

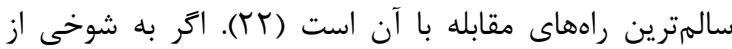
ديدكاه فيزيولوزى نكاه كنيم شوخى يديدهاى است كه از يك إنى طرف با مغز در ارتباط است و از سوى ديخر حاوى تاثيرات

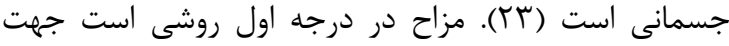

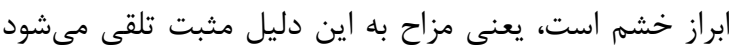

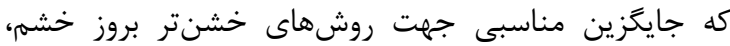
توهين و ناسزاگويى است. مزاح حاصل كنار هم كذاشتن و

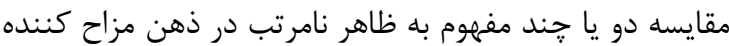

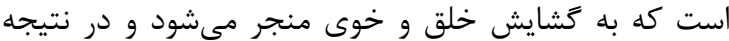

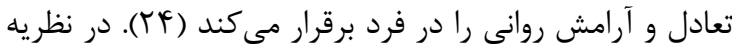
كاهش تنش، ذكر شده كه شوخى شيوه قابل يذيرش اجتماعى آنى

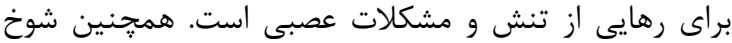
طبعى به عنوان ابزارى براى كاهش اضطراب به كار كرفتي

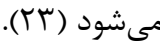

در سه دهه كذشته به منظور كاهش فشارهاى روانى مرتبط با بيمارىها و سالمندى، توجه بسيار جدى بر روى قدرته

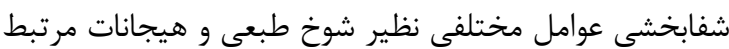

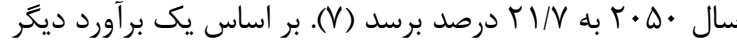

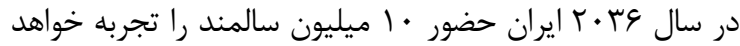

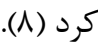
سالمندى جمعيت يِامدهاى فردى و اجتماعى گَوناگونى را به

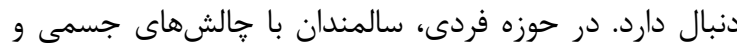
روانى متعددى مواجه هستند كه در صورت عدم مديريت، مىتواند קييامدهاى اسفناكى را به دنبال داشته باشد (9).

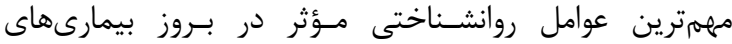
جسمى، استرس و اضطراب است. عوامل روان شناختى نه تنها

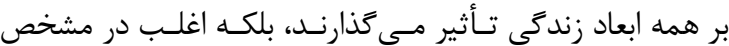
شدن نتيجه مقابله با يك بيمارى مزمن نقش مهرئ ائرى ايفا

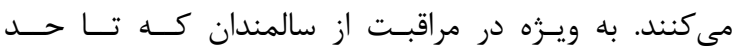

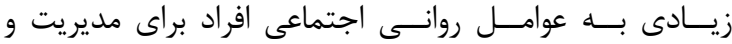
دستيابى به كنترل مناسب اين بيمـارى وابسـته اسـت (• (1). تغييراتى كه در وضعيت شناختى سالمند ايجاد مىشود منجر به بروز تغييرات قابل ملاحظهاى در عملكرد اكثر سيستمهاى بدن مىشود (1). يافتههاى مطالعات نشان داده است كه اكثر

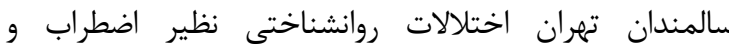

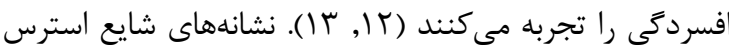
و اضطراب در سالمندان شامل دردهاى مزمن عضلات، سردرد،

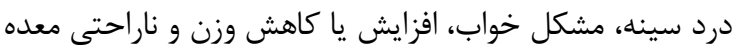
است. اين در حالى است كه استرس در بعضى از سالمندان منجر به مشكلهاى پيجيده ترى مانند افسردكى و ناتوانى

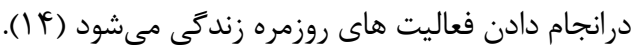

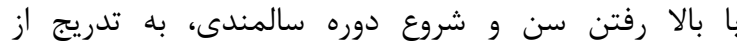
فعاليتهاى روانى و اجتماعى افراد كاسته مىشود كه ائن عامل خود باعث افزايش افسردگى، احساس ناميدى، انزوا،

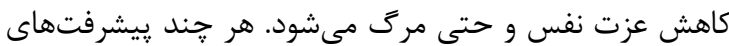
علمى و تكنولوزيك زيادى صورت كرفته، ولى اختلالاتى نظير افسردىى هنوز به عنوان بيمارى هاى شايع قرن محسوب

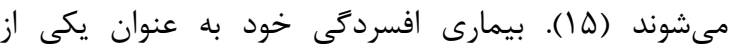
شايعترين اختلالات روانيزشكى در دوره سالمندى به شمار

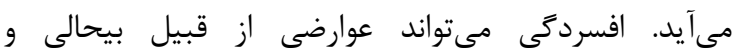
بى حوصلكى، خستَىى، مشكل تمركز، كاهش اشتها، ناميدى، مشكلات خواب و داشتن دردهاى جسمى را براى انسان به إنه

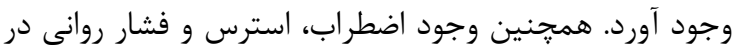
زندگى انسان مشكلات متعدد و تأثيرات منفى بر روى سلامتى

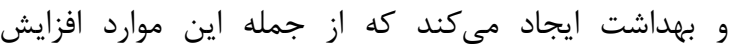

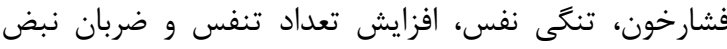
است (1), IV). عليرغم اين عوارض اسفناك، براساس كزارش 
خانواده هاى آنان به ادامه همكارى يـس از شـروع يـرَوهش، فـوت

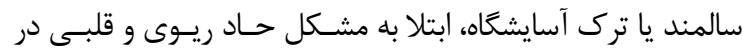

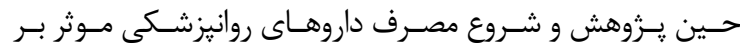
هوشيارى در طى دوران يزوهش به عنوان معيار حـذف از مطالعـهـ

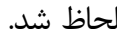

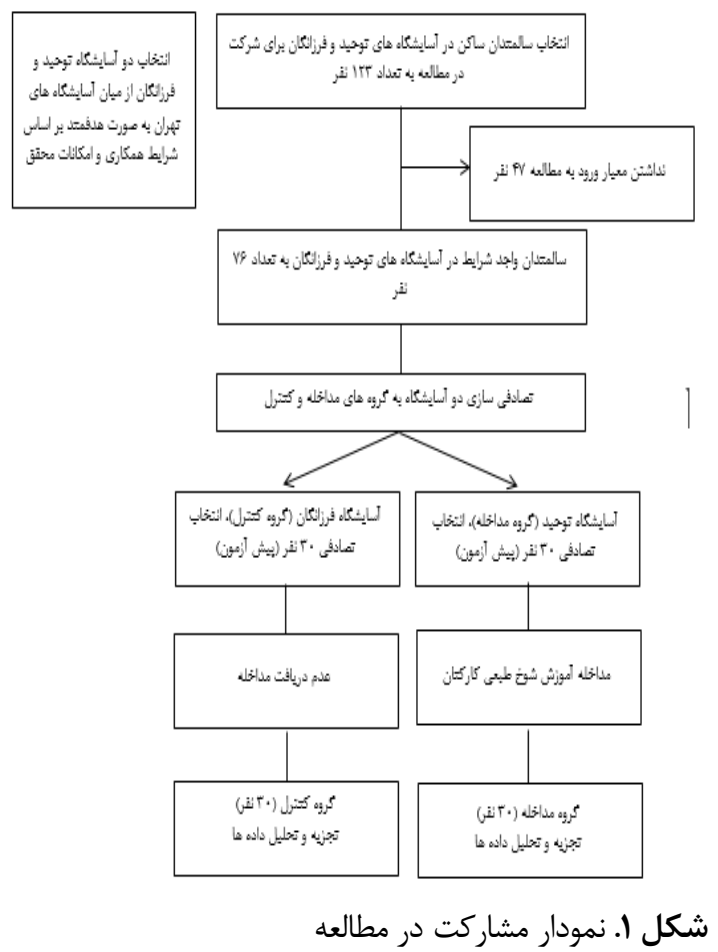

جلسات مداخله شامل V جلسه / 1/ ساعته در طلى يـك مـاه (ســه

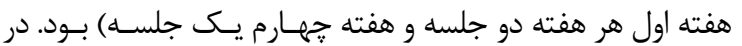
ابتدا جلسهاى با حضور كاركنان مركز توحيد (مركز منتخـب بــراى

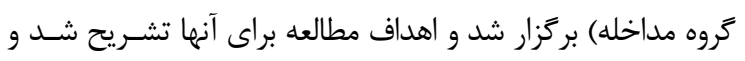
رضايت آكاهانه آنان اخذ شد. سيس دو جرو جلسه (مجزا در آسايشـعاه

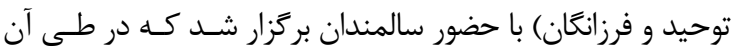
هدف از انجـام يـرزوهش و روش كـار توضـيح داده شـــ و رضـايت آكاهانه نمونهها اخذ شد. در اين جلسه توضيحاتى در زمينـهـ نحـوه تكميل :رسشنامهها ارايه شد و ييش آزمون بركَزار شـد. در طـى

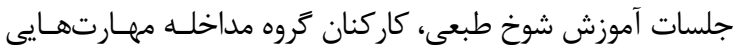

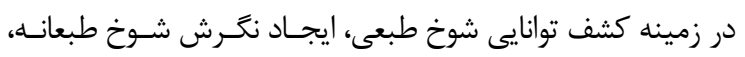
توانايى خنديدن، لطيفه گويى و باز گويى مطالب خندهدار، اسـتفاده

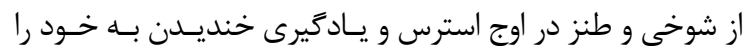

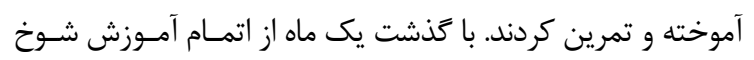

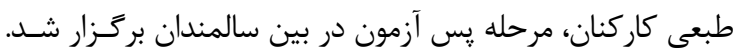
فرضيات اين يزوهش به صورت ذيل بود:
با آن شده است (YD). اين مداخلات مىتواند با اجرا بر روى سالمندان، زمينه را براى بهبود شرايط روانشناختى آنها فراهم

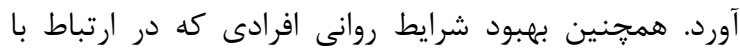
سالمندان هستند مىتواند رِيامدهاى مثبتى به همراه داشته باشد. در اين راستا در مراكز نگگهدارى سالمندان بهبود شرايط روحى و روانى كاركنان مى تواند بر رضايت شغلى و عملكرد

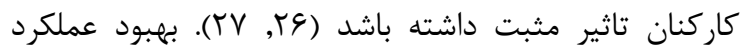
كاركنان و همجنين كاهش تنشهاى روانى آنها جهت برقرارى

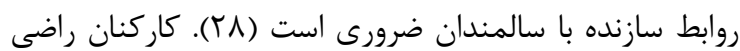
و متعادل از نظر روانى مىتوانند به شيوهاى موثر نيازهاى

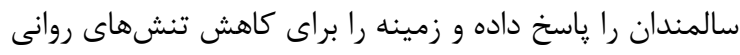

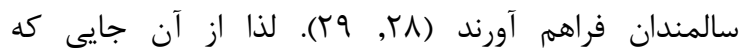
بيماريهايى نظير افسردگى، اضطراب و استرس مىتوانند بر كيفيت زندگى سالمندان كه شامل عملكرد مطلوب در ابعاد جسمانى و روانشناختى است، اثرات منفى داشته باشد، اين

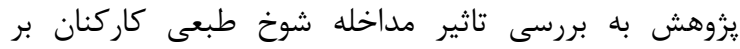

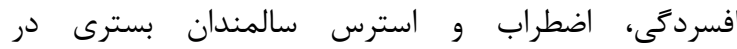
آسايشعاههاى منتخب شهر تهران در سال Vوس ا يرداخت.

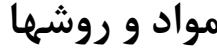

يزوهش حاضر يك مطالعه كارآزمايى بالينى تصادفى شده با طـرح

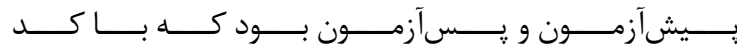
IRCT20190207042652N1

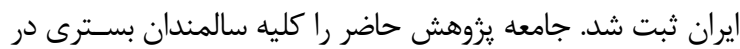

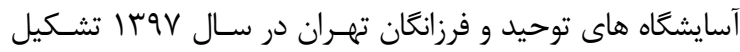
دادند. حجم نمونه با اطمينان هو درصد، توان آزمون ه/ • و انـدازه

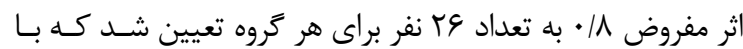

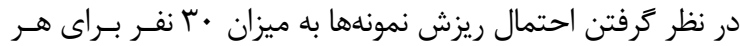

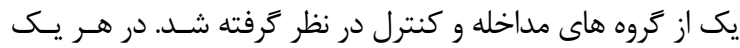

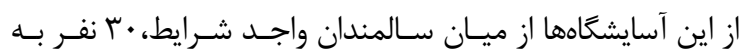
صورت تصادفى ساده انتخاب شدند و سيس به صـورت تصـادفى و

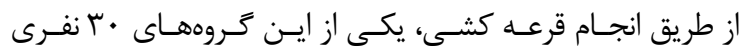

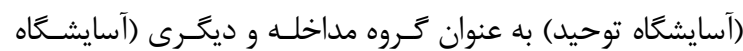
فرزانگان) به عنوان گَروه كنتــرل در نظـر گرفتـه شـد (شـكل (). معيارهاى ورود به مطالعه شامل داشتن تمايل جهـت همكـارى در

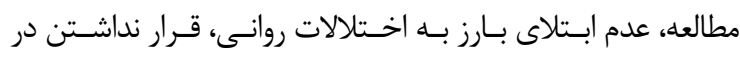
مرحلـه مـزمن بيمـارى ريـوى، برخــوردارى از هوشـيارى كامـل،

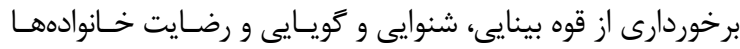

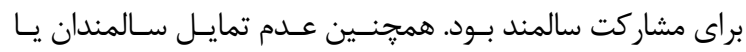


روان يرستاران و اعضاى هيئت علمى قرار كرفت و روايى محتـوايى تر زيى

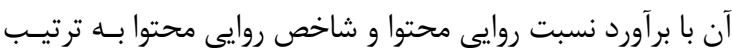

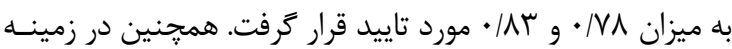

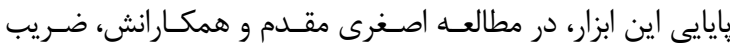

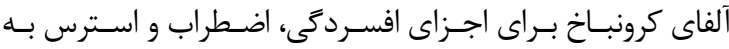

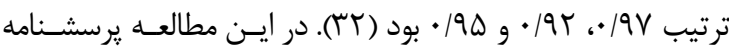
قبل از توزيع ميان نمونههاى يزوهش، توسط • ا نفر از سـالمندان

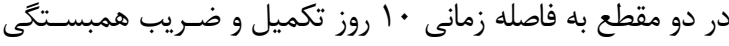

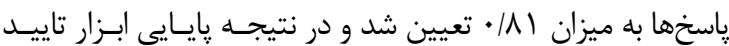

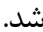

براى تحليل دادهها از نرم افزار SPSS نسخه بَ اسـتفاده شـد. بـر اساس نتيجه به دسـت آمـده از آزمـون كولمـوكروف- اسـميرنوف كارف

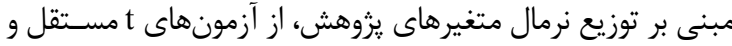

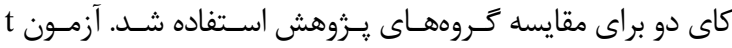

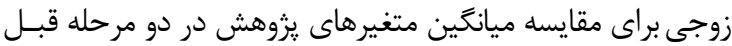

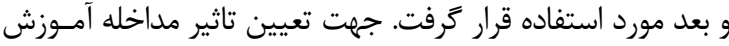
شوخ طبعى كاركنان بر افسردىى، اضطراب و استرس سالمندان از

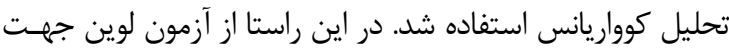

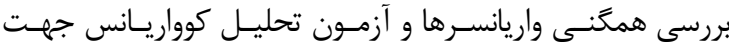

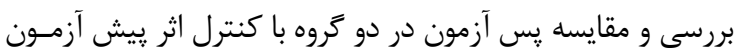

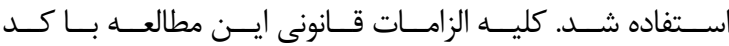
IR.IAU.TMU.REC.1397.020 مورد تاييد قرار كرفته است.

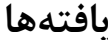

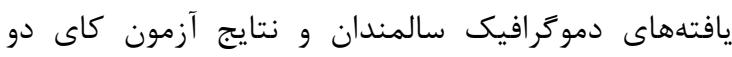
براى بررسى اختلاف دو گروه از نظر متغيرهاى دموكر افيك دافي

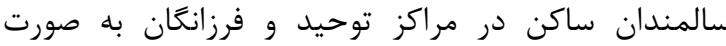
جدول r است. ميانكين (土 انحراف معيار) سن مشاركت

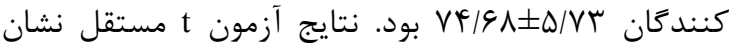

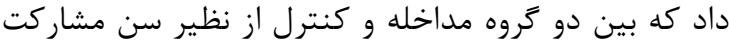

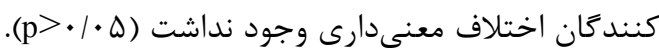
نتايج آزمون t مستقل نشان داد كه در مرحله يیش دآ آزمون

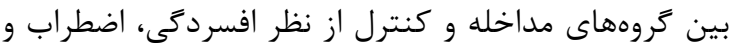

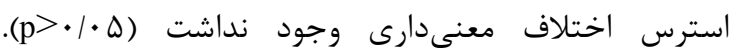

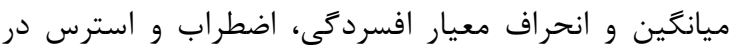

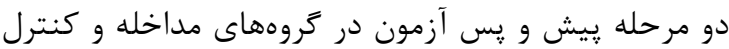

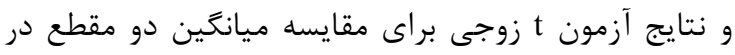

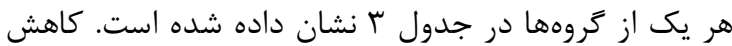

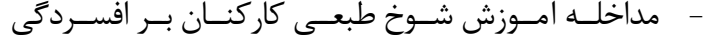

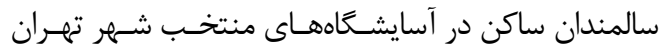

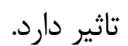
- مداخله آموزش شوخ طبعى كاركنان بر اضطراب سالمندان ساكن در آسايشكاههاى منتخب شهر تهران تاثير دارد. - مداخله آموزش شوخ طبعى كاركنان بر استرس سـالمندان

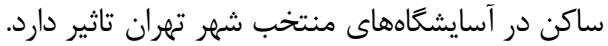

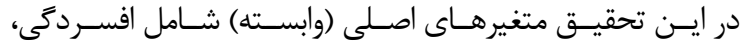

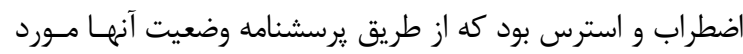

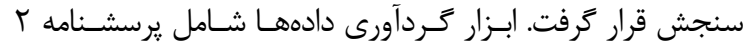
قسمتى (اطلاعات دموكرافيك سالمندان و يرسشـنامه افسـردخى،

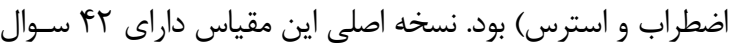

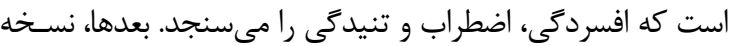

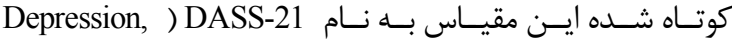
(Anxiety, Stress

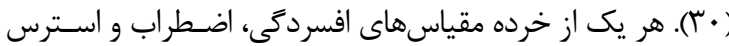

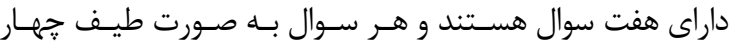

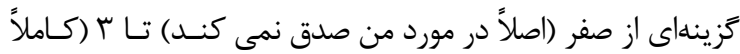

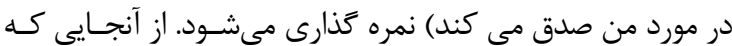

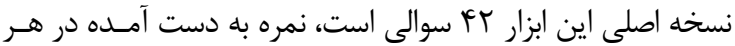

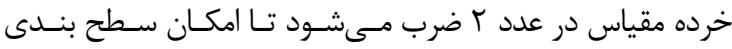

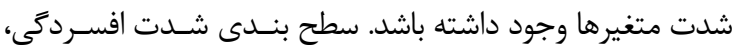

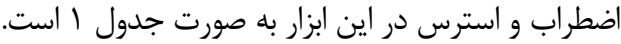

جدول ا. شدت نتايج هر يـك از خــده مقيـاسهـاى ابـزار افسـردىى،

\begin{tabular}{|c|c|c|c|}
\hline استرس & اضطراب & افسردىى & شدت \\
\hline$\cdot-14$ & $\cdot-\gamma$ & $\cdot-9$ & عادى \\
\hline $10-11$ & $1-9$ & $1 \cdot-1 \pi$ & خفيف \\
\hline 19-ra & $1 \cdot-1 F$ & $\mid f-r$. & متوسط \\
\hline TS-זT & $10-19$ & YI-TV & شديد \\
\hline$>r F$ & $>r$. & $>r \Lambda$ & بسيار ث \\
\hline
\end{tabular}

صاحبى و همكارانش براى بررسى اعتبـار مـلاك ابـزار DASS از از

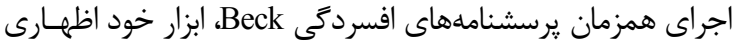

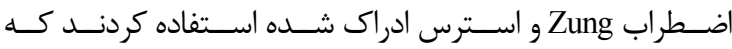

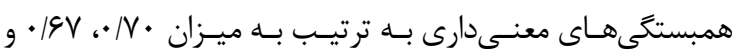

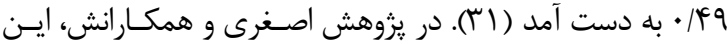
يرسشنامه توانست بين نمونههاى جمعيت عمومى و بيماران مبتلا

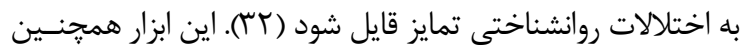
در مطالعه حاضر براى تعيين روايى محتوايى در اختيار تعـدادى از 
جدول r. فراوانى و درصد نمونهاى ثروهش بر اساس متغيرهاى دموكر افيك در سالمندان

\begin{tabular}{|c|c|c|c|c|}
\hline \multirow[t]{2}{*}{$\mathrm{p}$-value } & كنترل & مداخله & \multirow[t]{2}{*}{ متغير } & \\
\hline & $\mathrm{F}(/)$. & $\mathrm{F}(\%)$ & & \\
\hline \multirow[t]{3}{*}{$1 / \cdots$} & & & & جنسيت \\
\hline & $10(\Delta \cdot / \cdot)$ & $10(\Delta \cdot / \cdot)$ & 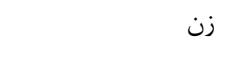 & \\
\hline & $10(\Delta \cdot / \cdot)$ & $10(\Delta \cdot / \cdot)$ & 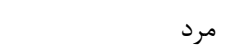 & \\
\hline \multirow[t]{6}{*}{. IDTV } & & & & سطح تحصيلات \\
\hline & $9(r \cdot 1 \cdot)$ & $f(\mid r / r)$ & بيسواد & \\
\hline & $r(1 \cdot 1 \cdot)$ & $9(T \cdot 1 \cdot)$ & ابتدايى & \\
\hline & $9(r \cdot / \cdot)$ & $\Delta(\mid \& / V)$ & زير دييلم & \\
\hline & $\wedge(\Gamma G / V)$ & $11(r \varphi / V)$ & دييلم & \\
\hline & $f(\mid r / r)$ & $f(\mid r / r)$ & فوق دييلم و ليسانس & \\
\hline \multirow[t]{4}{*}{$\cdot / V Y \wedge$} & & & & وضعيت تاهل \\
\hline & $1(r / \Gamma)$ & $r(g / V)$ & مجرد & \\
\hline & $V(r / r)$ & $\Delta(\mid \& / V)$ & متاهل & \\
\hline & $r T(Y r / F)$ & $r r(V \& \mid 9)$ & مطلقه/فوت شده & \\
\hline \multirow[t]{5}{*}{$\cdot|\mathrm{A}|$} & & & & تعداد فرزند \\
\hline & $9(r \cdot / \cdot)$ & $9(r \cdot 1 \cdot)$ & ا فرزند و كمتر & \\
\hline & $V(T / T)$ & $\Delta(\mid g / N)$ & ك ف فرزند & \\
\hline & $9(r \cdot / \cdot)$ & $V(Y r / Y)$ & ب برزند & \\
\hline & $\Lambda(\Gamma \& / V)$ & $\| r(F \cdot / \cdot)$ & ع فرزند و بيشتر & \\
\hline
\end{tabular}

نتايج تحليل كوواريانس جهت تعيين اثربخشى مداخله شوخ طبعى كاركنان در زمينه افسردكى سالمندان حاكى از موثر تراني

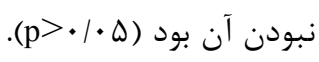

\section{بحث}

در اين مطالعه تاثير مداخله شوخ طبعى كاركنان بر روى إني

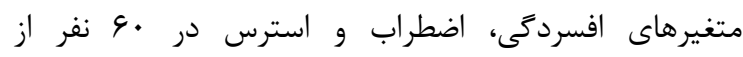

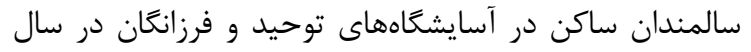

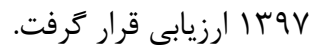

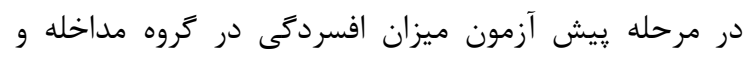

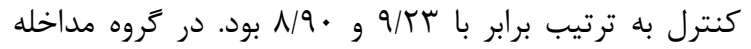
وضعيت افسردكى س/r/ ها درصد از مشاركت كنندكان در سطح

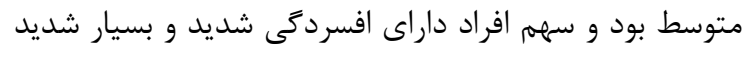

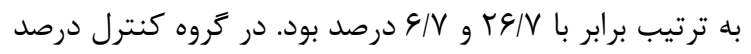

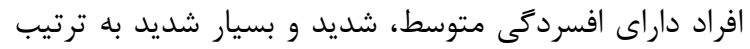

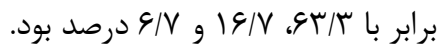

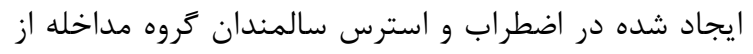

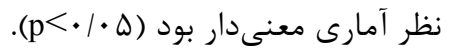

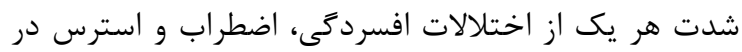

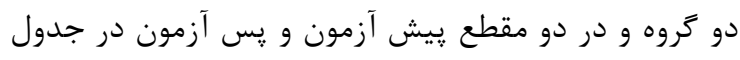

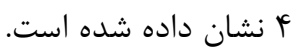

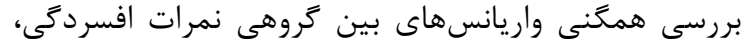

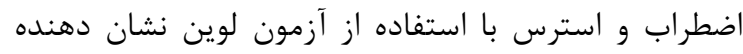

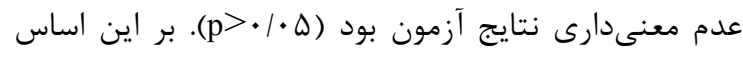

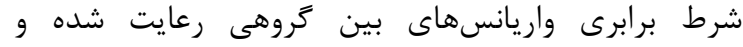

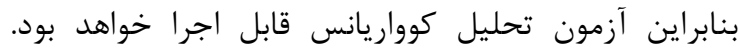

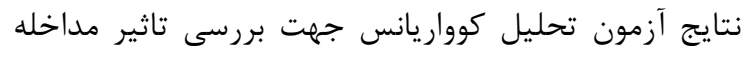

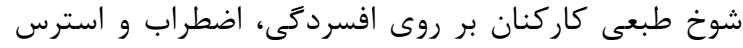

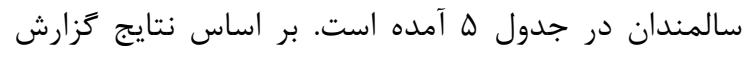

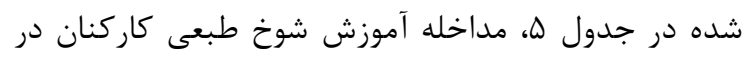

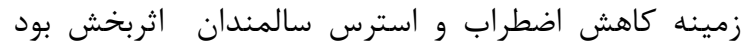

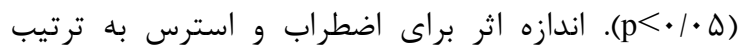

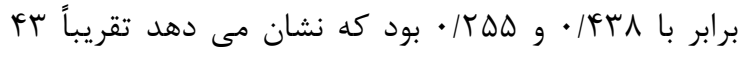

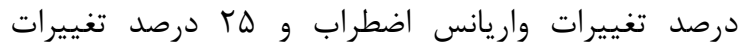
واريانس استرس ناشى از متغير مستقل است. 
جدول r. وضعيت افسردگى، اضطراب و استرس سالمندان گروههاى مداخله و كنترل در دو مرحله ييش آزمون و يس آزمون

\begin{tabular}{|c|c|c|c|c|c|c|c|c|}
\hline \multicolumn{2}{|c|}{ آزمون تى زوجى } & \multicolumn{2}{|c|}{ كنترل } & \multicolumn{2}{|c|}{ آزمون تى زوجى } & \multicolumn{2}{|c|}{ مداخله } & \multirow[t]{2}{*}{ متغير } \\
\hline p-value & $\mathrm{t}$ & يس آزمون & يِش آزمون & $\mathrm{p}$-value & $\mathrm{t}$ & يس آزمون & يِش آزمون & \\
\hline$\cdot / 1 \wedge \Lambda$ & $-1 / Y K V$ & $q / \xi r \pm r / \cdot V$ & $N / q \cdot \pm r / 4 q$ & .1 .91 & $1 / 190$ & $N / F \cdot \pm r / r$ & $q / r r \pm r / \Delta q^{*}$ & افسردگى \\
\hline$\cdot 11 \cdot 9$ & $-1 / 9 \Delta T$ & $\mid r / \cdot 9 \pm 1 / 91$ & $11 / r \cdot \pm r / \Delta 9$ & $<\cdot / \cdot \cdot 1$ & $r / q v q$ & $9 / r \cdot \pm 1 / V r$ & $\| / r \varepsilon \pm r / V$. & اضطراب \\
\hline$\cdot|\Delta r|$ &. $\mid G \mu F$ & $\mid r / r r \pm r / r q$ & $\mid r / q \cdot \pm r / q$. & $</ \cdot \cdot 1$ & V/ATr & $11 / \Lambda 9 \pm r / \Delta T$ & $|\Delta / r \cdot \pm r / \Delta|$ & استرس \\
\hline
\end{tabular}

جدول F. شدت افسردگى، اضطراب و استرس سالمندان گروههاى مداخله و كنترل در دو مرحله يِيش آزمون و يس آزمون

\begin{tabular}{|c|c|c|c|c|c|}
\hline \multicolumn{2}{|c|}{ كنترل } & \multicolumn{2}{|c|}{ مداخله } & \multirow[t]{3}{*}{ شدت } & \multirow[t]{3}{*}{ متغير } \\
\hline ڤس آزمون & پِيش آزمون & يس آزمون & يِش آزمون & & \\
\hline $\mathrm{F}(/)$. & $\mathrm{F}(\%)$ & $\mathrm{F}(\%)$ & $\mathrm{F}(\%)$ & & \\
\hline$\cdot(\cdot / \cdot)$ & $1(\Gamma / \Gamma)$ & $1(r / \mu)$ & $1(T / \Gamma)$ & عادى & افسردخى \\
\hline$r(\varepsilon / V)$ & $r(1 \cdot / \cdot)$ & $f(\mid r / F)$ & $r(1 \cdot 1 \cdot)$ & خفيف & \\
\hline $19(\Delta r / \Gamma)$ & $19(\mathcal{G} / \widetilde{T})$ & $r)(V \cdot / \cdot)$ & $19(\Delta T / T)$ & متوسط & \\
\hline $11(r G / V)$ & $\Delta(\mid \& / V)$ & $F(\mid r / T)$ & $\wedge(Y G / V)$ & شديد & \\
\hline $1(r / \Gamma)$ & $r(g / V)$ & $\cdot(\cdot / \cdot)$ & $r(g / V)$ & بسيار شديد & \\
\hline$\cdot(\cdot / \cdot)$ & $\cdot(\cdot / \cdot)$ & $\cdot(\cdot / \cdot)$ & $\cdot(\cdot / \cdot)$ & عادى & اضطراب \\
\hline$\cdot(\cdot / \cdot)$ & $\cdot(\cdot / \cdot)$ & $\cdot(\cdot / \cdot)$ & $\cdot(\cdot / \cdot)$ & خفيف & \\
\hline $1(r / r)$ & $r(\varepsilon / V)$ & $\Delta(\mid q / 9)$ & $r(1 \cdot / \cdot)$ & متوسط & \\
\hline$r(1 \cdot 1 \cdot)$ & $\Delta(\mid \& / V)$ & If $(f G / V)$ & $V(Y M / T)$ & شديد & \\
\hline TG (^G/V) & r (V\&|G) & $\|(\Psi \varepsilon / V)$ & $r \cdot(99 / V)$ & بسيار شديد & \\
\hline$\cdot(\cdot / \cdot)$ & $\cdot(\cdot / \cdot)$ & $r(\varepsilon / V)$ & $\cdot(\cdot / \cdot)$ & عادى & استرس \\
\hline$\cdot(\cdot / \cdot)$ & $1(r / \Gamma)$ & $r(1 \cdot / \cdot)$ & $r(\xi / V)$ & خفيف & \\
\hline$V(Y T / K)$ & $V(Y r / T)$ & $q(\Gamma \cdot / \cdot)$ & $\cdot(\cdot / \cdot)$ & متوسط & \\
\hline$I V(\Delta \varphi / V)$ & If $(f \in / V)$ & $19(\Delta \Gamma / \Gamma)$ & $19(9 / / T)$ & شديد & \\
\hline$q(r \cdot / \cdot)$ & $\Lambda(Y G / V)$ & $\cdot(\cdot / \cdot)$ & $q(r \cdot / \cdot)$ & بسيار شديد & \\
\hline
\end{tabular}

جدول ه. تحليل كوواريانس براى تعيين اثربخشى مداخله شوخ طبعى كاركنان بر افسردگى، اضطراب و استرس سالمندان

\begin{tabular}{|c|c|c|c|c|c|c|}
\hline Effect size & p-value & $\mathrm{F}$ & Mean squares & df & Sum of squares & منبع تغييرات \\
\hline$\cdot 1 \cdot \Delta V$ & .1 .91 & $r / 4 \in F$ & .1994 & 1 & .1984 & يِيش آزمون (افسردگى) \\
\hline- & - & - & $\cdot / T V A$ & $\Delta V$ & $1 \Delta / \wedge \Delta q$ & خطا \\
\hline$\cdot / f r \Lambda$ & $<\cdot 1 \cdot \cdot 1$ & 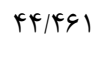 & $৭ / ৭ \wedge \Delta$ & 1 & $৭ / ৭ \wedge \diamond$ & يِي آزمون (اضطراب) \\
\hline- & - & - &.$/ T r \Delta$ & $\Delta V$ & $\mid r / \Lambda \cdot 1$ & خطا \\
\hline$\cdot / r \Delta \Delta$ & $<\cdot 1 \cdot \cdot 1$ & $19 / 01$. & N/THV & 1 & N/THV & ييش آزمون (استرس) \\
\hline - & - & - & . MtT & $\Delta V$ & $T F / .99$ & خطا \\
\hline
\end{tabular}

سالمندان، مطالعهاى در اصفهان نشان داد كه ميانگين نمره

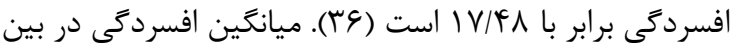
سالمندان اصفهان بسيار بيشتر از مطالعه حاضر است. در اين

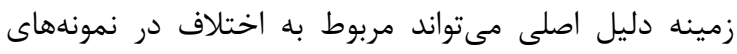
مورد بررسى باشد؛ در مطالعه مذكور نمونه مورد بررسى از مدئ ميان سالمندان مبتلا به ديابت انتخاب شده بود كه اين ابتلا
شيوع افسردگى در جين برابر با / / در حالى است كه يافتههاى مطالعهاى در هند نشان داد كه

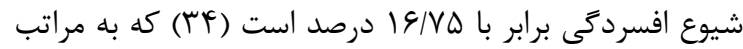

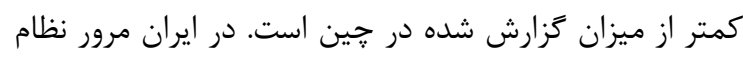

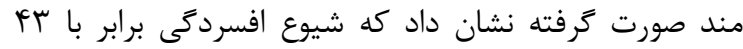
درصد است (ه广). در بررسى ميزان افسردىى در بين 


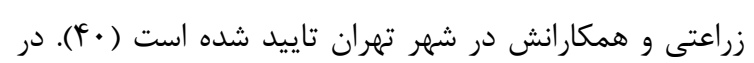

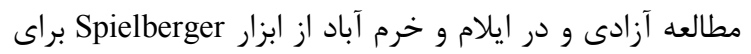

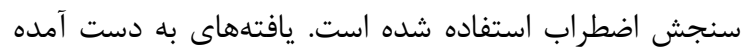

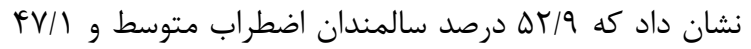

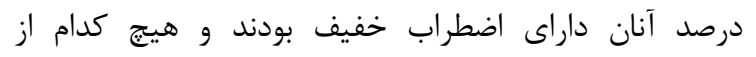

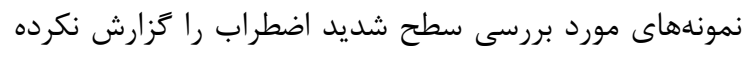

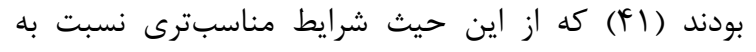

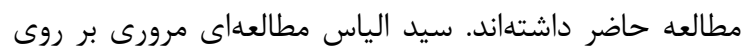

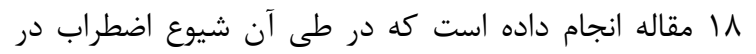

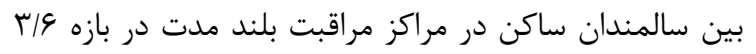

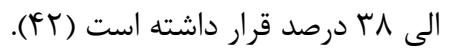

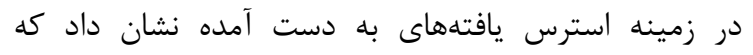

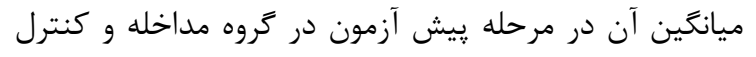

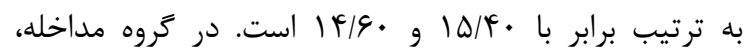

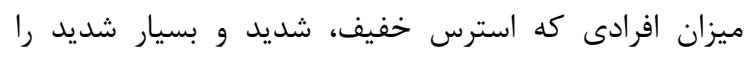

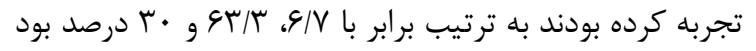

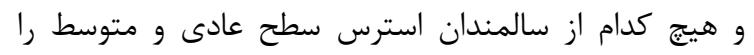

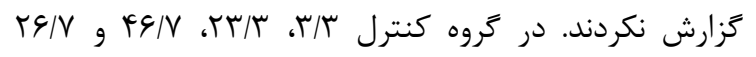
درصد افراد به ترتيب در طيف استرس خفيف، متوسط، درد شديد

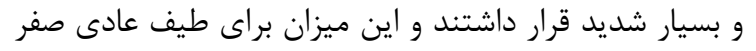

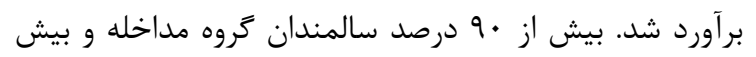

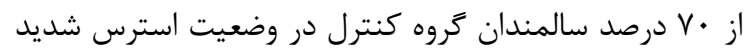

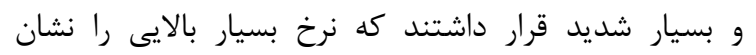

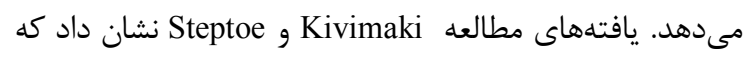

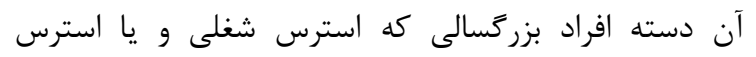

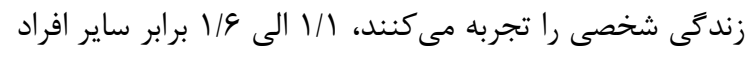

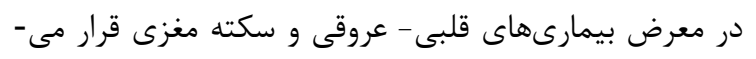

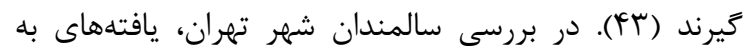

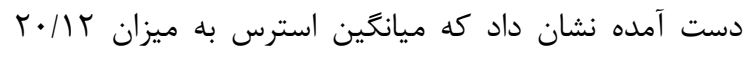

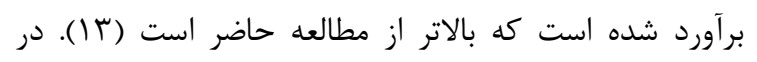

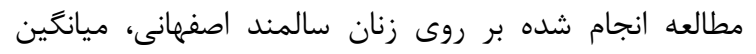

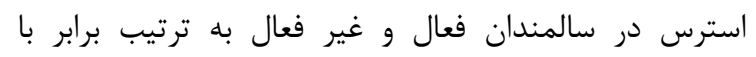

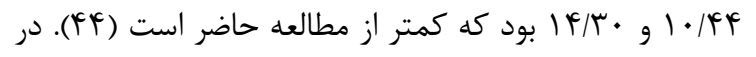

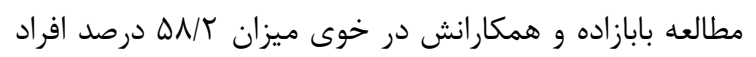

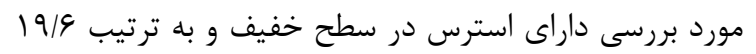

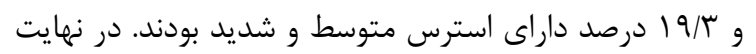

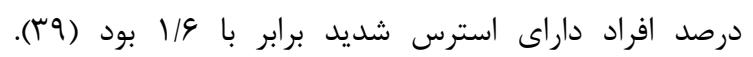

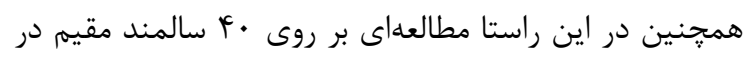

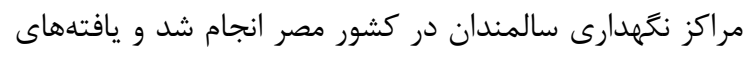
به دست آمده نشان داد كه درصد افراد داراى استرس خفيف، دران

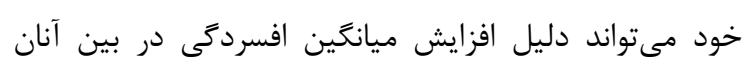

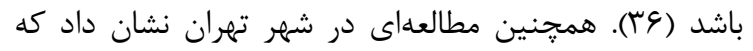

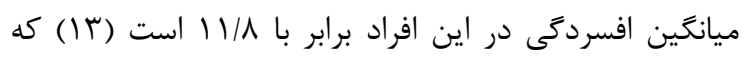

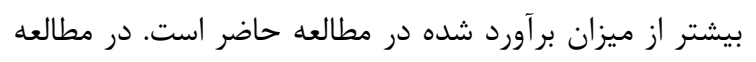

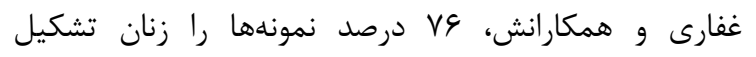
ميدادند كه مىتواند توجيه كننده تفاوت مشاهده شداره

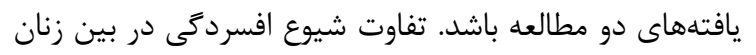

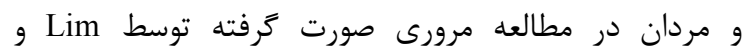

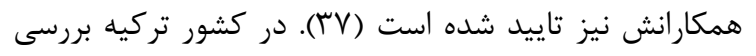

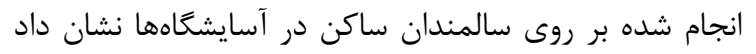

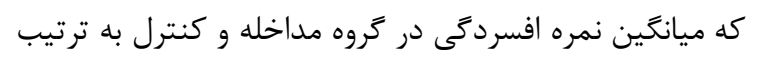

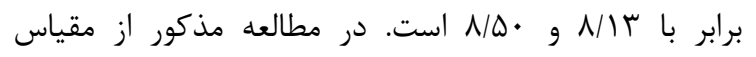

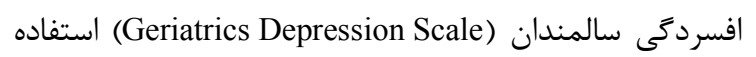

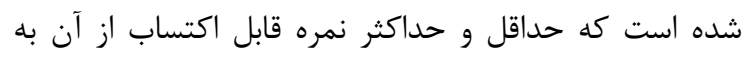

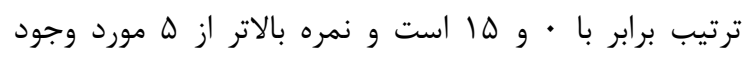

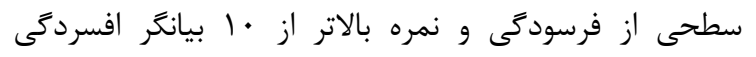

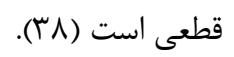
يافتههاى به دست آمده در زمينه اضطراب نشاب نشان داد كه

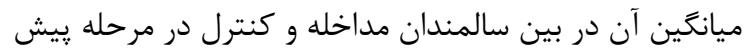

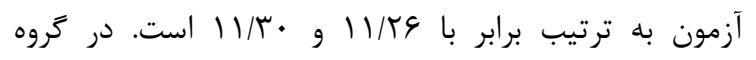
مداخله 99/V درصد نمونهها اضطراب شديد راب رات تجربه كردهاند.

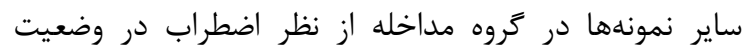

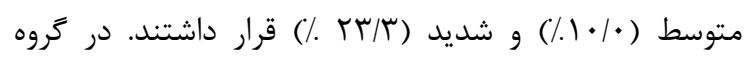
كنترل سهم افراد در وضعيت اضطراب متوسط، شديد و بسيار

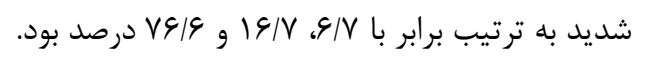

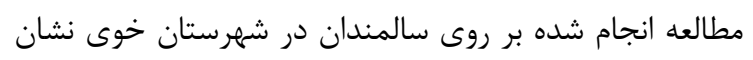
داد كه درصد سالمندان داراى اضطراب متوسط، شديد و بسيار

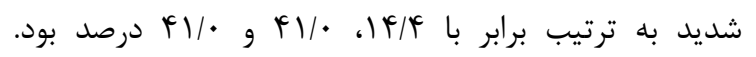

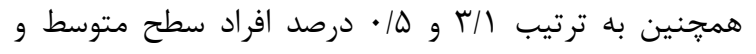

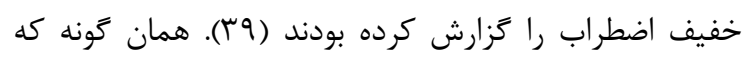

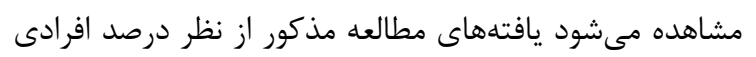

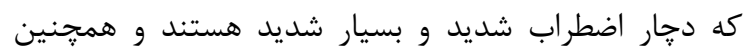

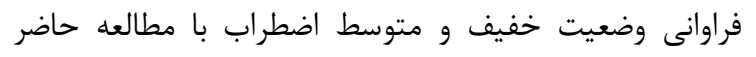

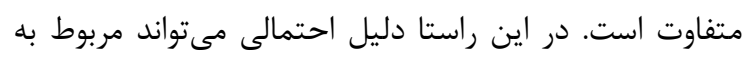

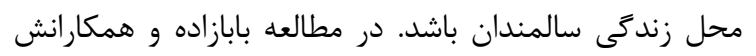

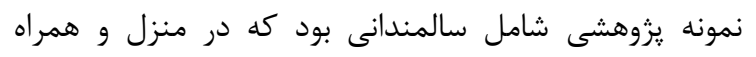

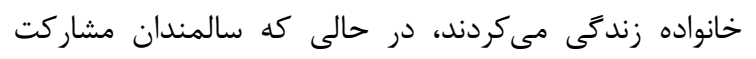

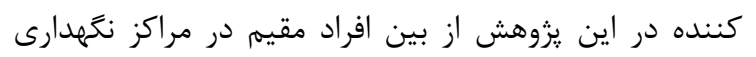

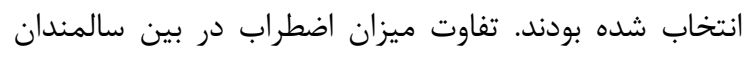

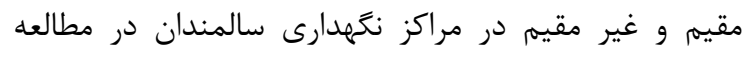


داد. همجنين شوخ طبعى و آموزش آن مىتواند از طريق تاثير

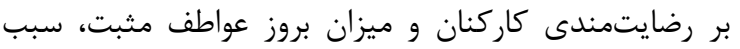
كاهش و تخفيف علايم اختلالات روانشناختى در سالمندان شود. شوخ طبعى سبب بروز احساسات مثبت و عواطف مثبت

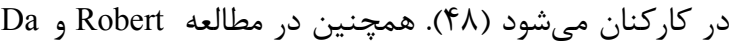
Motta Veiga با ميزان رضايت شغلى كاركنان در ارتباط است (YV) (TV). رضايت شغلى بالا با عملكرد بهتر و با كيفيتتر ارتباط مستقيم دارد (F9). شواهد موجود نشان مئدهند كه رضايت كاركنان

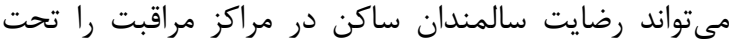

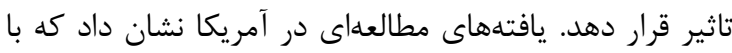
افزايش ا نمره در رضايت كاركنان، ميزان رضايت سالمندان

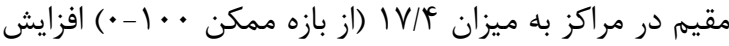
مىيابد (ج)). بر اين اساس مىتوان اظهار داشت كه از طريق شوخ طبعى و با اثركذارى بر وضعيت روانشناختى كاركنان، مى توان وضعيت رضايت شغلى آنان را افزايش داد و واز إين طريق سبب بهبود وضعيت رضايت سالمندان ساير ريامدهاى

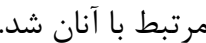
نتايج اين مطالعه شواهدى را فراهم مى كند كه تاييد كننده

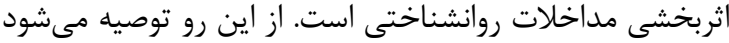

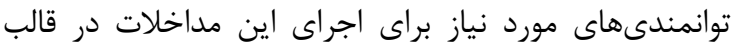
برنامههاى آموزشى به كروه هدف مربوطه يعنى يرستاران بهائ

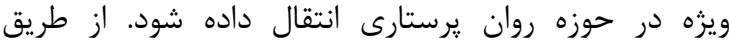
كنجاندن واحدهاى مربوطه در كوريكولومهاى آموزشى و همجنين آموزش كار كاهى و عملى مى توان اين توانمندى دانها

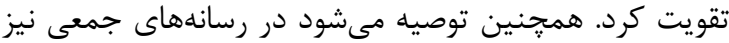

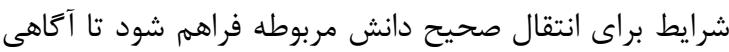
و نكرش عموم در زمينه اجراى خنين مداخلاتى تغيير كند و شرايط براى بهرهمندى از آن فراهم شود. در اين راستا طراحى درائ

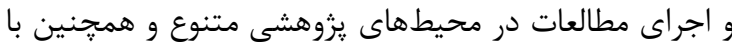
كروههاى هدف متفاوت، مىتواند قضاوت در مورد اثربخشى اين مداخلات را مستدلتر كند؛ لذا انجام مطالعات بيشتر در اين زمينه پِيشنهاد مىشود. يافتههاى به دست آمده از اين مطالعه نشان داد كه در مرحله ريش آزمون اكثر سالمندان وضعيت افسردكى، اضطراب و استرس مطلوبى نداشتند و اكثر نمونههاى يزوهش سطوح متوسط تا بسيار شديدى از اختلالات روانشناختى مذكور را

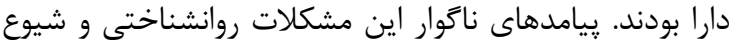
بالاى آن ايجاب مى كند كه براى كاهش و تخفيف اين علايم مداخلات اثربخش طراحى و اجرا شود. در اين راستا مطالعه

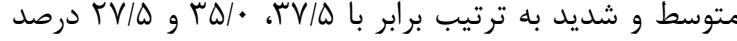

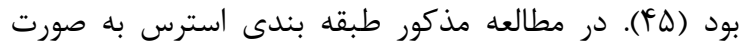
خفيف، متوسط و شديد بود و لذا با ابزار مورد استفاده در يروهش حاضر مطابقت جندانى ندارد. در گروه مداخله ميزان اضطراب و استرس در مرحله ئله آزمون نسبت به مرحله ييش آزمون به صورت معنى مدارى كاهش يافت. همجنين نتيجه تحليل كوواريانس نشان دهنده اثربخشى مداخله شوخ طبعى كاركنان در زمينه كاهش اضطراب و استرس سالمندان بود. در اين راستا شواهدى وجود دارد كه مىتواند توضيح دهنده اثربخشى اين مداخله بر روى متغيرهاى اضطراب و استرس سالمندان باشد. شوخ طبعى به إنه فرد اجازه مىدهد ترسها و ديخر احساسات منفى خود را با با بال

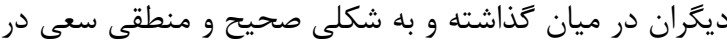

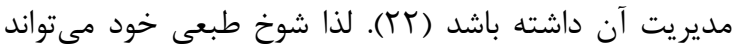

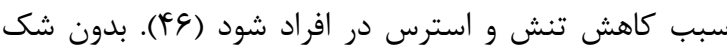
كاهش تنش در كاركنان شرايط مناسبى براى ايفاى نقش آنان

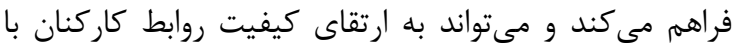
سالمندان منجر شود كه اين عامل بر وضعيت مولفههاى روانشناختى سالمندان تاثير گذار خواهد بود. شوخ طبن إنى مى (واند عملكرد اجتماعى و روابط افراد را تحت تاثير قرار دهد

و Chipps در مطالعه خود به اين نتيجه رسيدند كه وجود ارتباطات در بين افراد در اين محيطها به صورت مستقيم و مثبت با وضعيت روانشناختى سالمندان در ارتباط است (V) أV). يافتههاى اين مطالعه تاييد كننده تاثير ارتباطات بر روى متغيرهاى دموكرافيك سالمندان است. يكى ديكر از إنائ مسيرهاى اثركذارى شوخ طبعى كاركنان بر روى يُ يامدهاى افراد سالمند در مراكز نكَهدارى سالمندان، تاثير شوخ طبعى لترى بر روى توانمندىهاى كاركنان و وضعيت روانشناختى آنها است. شوخ طبعى سبب كاهش فرسودى شغلى و افز افزايش تاب

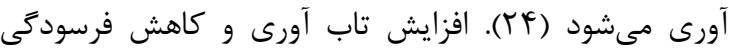
شغلى مىتواند عملكرد كاركنان را تحت تاثير قرار دهد.

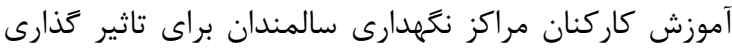

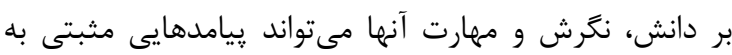

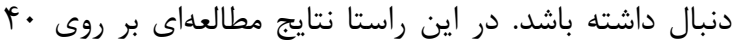

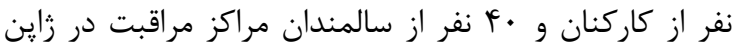
نشان داد كه آموزش مهارتهاى مراقبت فرد محور به كاركنان سبب افزايش كيفيت زندكى در سالمندان مىشود (צ؟). اين مطالعه نشان داد كه مى توان با تغيير در دانش و نكرش دانش كاركنان وضعيت متغيرهاى ذهنى سالمندان را تحت تاثير قرار 


\section{تقدير و تشكر}

مقاله حاضر برگرفته از يايان نامه مقطع كارشناسى ارشد رشته

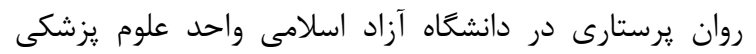

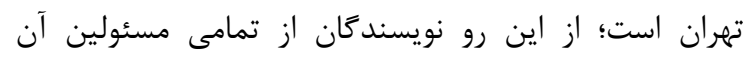

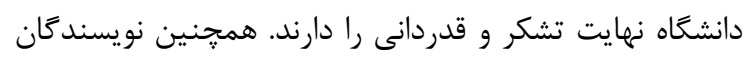

بر خود لازم مىدانند از مسئولين آسايشغاههاى توحيد و

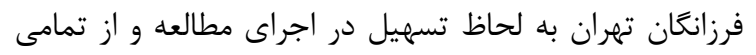

مشاركت كنند

$$
\begin{aligned}
& \text { حاضر شواهدى مبنى بر اثربخشى مداخله شوخ طبعى كاركنان } \\
& \text { بر روى ييامدهاى افسردگى، اضطراب و استرس در در سالمندان }
\end{aligned}
$$

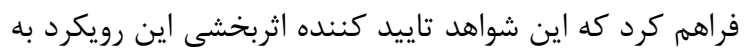

$$
\begin{aligned}
& \text { ويزه در كاهش معنى دار اضطراب و استرس است. مداخله } \\
& \text { آموزش شوخ طبعى، رويكردى كم هزينه و ايمن است كه } \\
& \text { مىتواند توسط روانشناسان و ساير افراد آموزش ديده ديده انجام } \\
& \text { شود. همجنين عدم نياز به شرايط منحصر به فرد و ويزه، }
\end{aligned}
$$

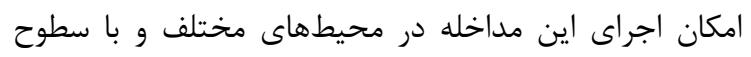

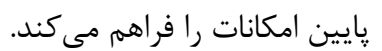

\section{REFERENCES}

1. WHO. World report on ageing and health. Geneva: World Health Organization; 2015.

2. Lyons AC, Grable JE, Joo S-H. A cross-country analysis of population aging and financial security. Agricultural and Consumer Economics 2018; 12:96-117.

3. Lee RD, Mason A. Population aging and the generational economy: a global perspective. New York: Edward Elgar Publishing; 2011.

4. Gavrilov L, Heuveline P. Aging of population. In: Demeny P, McNicoll G, Eds. The encyclopedia of population. New York: Macmillan Reference USA; 2003.

5. Bloom DE, Canning D, Fink G. Population aging and economic growth. Globalization and Growth $2010 ; 297$.

6. Hetzel L, Smith A. 65 years and over population: 2000: Census 2000 Brief. USA: DIANE Publishing; 2008.

7. Leila V, Abolghasem P,Batoul A, Ali AS. Quality assessment tools and Management for medication prescription in elderly. Hospital J 2013;11:4-12.

8. Mirzaie M, Darabi S. Population Aging in Iran and Rising Health Care Costs. Iranian Journal of Ageing 2017;12:156-169. [In Persian]

9. Hao G, Bishwajit G, Tang S, Nie C, Ji L, Huang R. Social participation and perceived depression among elderly population in South Africa. Clin Interv Aging 2017;12:971.

10. Ahern J, Matthay EC, Goin DE, Farkas K, Rudolph KE. Acute changes in community violence and increases in hospital visits and deaths from stress-responsive diseases. Epidemiology 2018;29:684-691.

11. Hawkley LC, Kocherginsky M. Transitions in loneliness among older adults: A 5-year follow-up in the National Social Life, Health, and Aging Project. Res Aging 2018;40:365-387.

12. Shahboulaghi M, Moghaddam AG, Khoshnou H, Karbalaee Z, Mohammadi M. mental health in the elderly and its predictive factors. World Family Medicine Journal 2017;7:314.

13. Ghafari M, Sharifirad G, Zanjani S, AH. Stress, Anxiety and Depression Levels Among Elderly Referrals to Tehran Elderly Club. Iranian Journal of Ageing 2012;7:53-59. [In Persian]

14. Christiansen J, Larsen FB, Lasgaard M. Do stress, health behavior, and sleep mediate the association between loneliness and adverse health conditions among older people? Soc Sci Med 2016;152:80-86.

15. Gharanjik A, Mohammadi Shahbolaghi F, Ansari G, Najafi F, Ghaderi S, Ashrafi K, et al. The Prevalence of Depression in Older Turkmen Adults in 2010. Iranian Journal of Ageing 2010;6:34-39. [In Persian]

16. Liu L, Gou Z, Zuo J. Social support mediates loneliness and depression in elderly people. J Health psychol 2016;21:750-758.

17. Keshavarzi S, Ahmadi SM, Lankarani KB. The impact of depression and malnutrition on health-related quality of life among the elderly Iranians. Glob J Health Sci 2015;7:161.

18. Schak KM, Vande Voort JL, Johnson EK, Kung S, Leung JG, Rasmussen KG, et al. Potential risks of poorly monitored ketamine use in depression treatment. Am J Psychiatry 2016;173:215-218.

19. Shulman B, Dueck R, Ryan D, Breau G, Sadowski I, Misri S. Feasibility of a mindfulness-based cognitive therapy group intervention as an adjunctive treatment for postpartum depression and anxiety. J Affect Disord 2018;235:61-67. 
20. Wellenzohn S, Proyer RT, Ruch W. Humor-based online positive psychology interventions: a randomized placebocontrolled long-term trial. J Posit Psychol 2016;11:584-594.

21. Randler C, Wüst-Ackermann P, Demirhan E. Humor reduces anxiety and disgust in anticipation of an educational dissection in teacher students. Int J Environ Sci Educ 2016;11:421-432.

22. Martin RA, Ford T, Eds. The psychology of humor: an integrative approach. Cambridge, Massachusetts: Academic press; 2018.

23. Savage BM, Lujan HL, Thipparthi RR, DiCarlo SE. Humor, laughter, learning, and health! A brief review. Adv Physiol Educ 2017;41:37-41.

24. Torgheh M, Alipour A. Effect of humour on burnout and resiliency of nurses. Journal of Holistic Nursing and Midwifery 2015;25:57-64. [In Persian]

25. Pérez-Aranda A, Hofmann J, Feliu-Soler A, Ramírez-Maestre C, Andrés-Rodríguez L, Ruch W, et al. Laughing away the pain: A narrative review of humour, sense of humour and pain. Eur J Pain 2019;23:220-233.

26. Yasuda M, Sakakibara H. Care staff training based on person-centered care and dementia care mapping, and its effects on the quality of life of nursing home residents with dementia. Aging Ment Health 2017;21:991-996.

27. Robert C, Da Motta Veiga S. Conversational humor and job satisfaction at work: exploring the role of humor production, appreciation, and positive affect. Humor 2017; 4:417-438.

28. Mahbobeh S, Rostambeygi P, Barkhordary M, Roshandel A. Effect of humor training on social function in nursing student of Islamic Azad University of Estahban. International Research Journal of Applied and Basic Sciences 2013;4:348-352. [In Persian]

29. Plaku-Alakbarova B, Punnett L, Gore R. Nursing home employee and resident satisfaction and resident care outcomes. Saf Health Work 2018:408-415.

30. Lovibond PF, Lovibond SH. The structure of negative emotional states: Comparison of the Depression Anxiety Stress Scales (DASS) with the Beck Depression and Anxiety Inventories. Behav Res Ther 1995;33:335-343.

31. Sahebi A, Asghari MJ, Salari RS. Validation of depression anxiety and stress scale (DASS-21) for an Iranian population. Iran Psychol 2005;4:299-313.

32. Asghari A, Saed F, Dibajnia P. Psychometric properties of the Depression Anxiety Stress Scales-21 (DASS-21) in a non-clinical Iranian sample. Int J Psychol 2008;2:82-102.

33. Zhang C, Xue Y, Zhao H, Zheng X, Zhu R, Du Y, et al. Prevalence and related influencing factors of depressive symptoms among empty-nest elderly in Shanxi, China. J Affect Disord 2019;245:750-756.

34. Rathod MS, Dixit JV, Goel AD, Yadav V. Prevalence of depression in an urban geriatric population in Marathwada region of Western India. Indian J Psychol Med 2019;41:32.

35. Sarokhani D, Parvareh M, Dehkordi AH, Sayehmiri K, Moghimbeigi A. Prevalence of depression among Iranian elderly: systematic review and meta-analysis. Iran J Psychol 2018;13:55.

36. Baharlooei O, Alavi M, Adelmehraban M. Psychosocial factors predicting length of hospitalization in elderly individuals with diabetes in selected hospitals of Isfahan University of Medical Sciences, Isfahan, Iran, in 2015. ARYA atheroscler 2017;13:103-108.

37. Lim GY, Tam WW, Lu Y, Ho CS, Zhang MW, Ho RC. Prevalence of Depression in the Community from 30 Countries between 1994 and 2014. Sci Rep 2018;8:2861.

38. Gök Ugur H, Yaman Aktaş Y, Orak OS, Saglambilen O, Aydin Avci İ. The effect of music therapy on depression and physiological parameters in elderly people living in a Turkish nursing home: a randomized-controlled trial. Aging Ment Health 2017;21:1280-1286.

39. Babazadeh T, Sarkhoshi R, Bahadori F, Moradi F, Shariat F, Sherizadeh Y. Prevalence of depression, anxiety and stress disorders in elderly people residing in Khoy, Iran (2014-2015). J Anal Res Clin Med 2016;4:122-128.

40. Zeraati M, Haghani Zemeidani M, Khodadadi Sangdeh J. The comparison of depression and death anxiety among nursing home resident and non-resident elderlies. Iran J Nurs 2016;29:45-54.

41. Azadi A, Taghinezhad H, Bastami M, Bastami A, Pashaei sabet F. The study amount of anxiety and depression among elderly diabetic patients referred to Shahid Mostafa Khomeini in Ilam and Shohada Ashayer Hospitals in Khoramabad, 2015. Iran J Nurs 2016;11:1-9.

42. Elias S. Prevalence of loneliness, anxiety, and depression among older people living in long-term care: a review. International Journal of Care Scholars 2018;1:39-43. 
43. Kivimäki M, Steptoe A. Effects of stress on the development and progression of cardiovascular disease. Nat Rev Cardiol 2018;15:215.

44. Arman M. The comparison of depression, anxiety and stress between active and inactive old women in Isfahan. J Rehab Med 2014;3:82-88. [In Persian]

45. Zaki M, Ahmed F, Sayed F. Effect of guided imagery in reduction of stress among elderly people in geriatric homes. Am J Nurs 2018;6:380-387.

46. Oktug Z. The moderating role of employees' humor styles on the relationship between job stress and emotional exhaustion. Int Bus Res 2017;10:131.

47. Chipps J, Jarvis M. Social capital and mental well-being of older people residing in a residential care facility in Durban, South Africa. Aging Ment Health 2016;20:1264-1270.

48. Wijewardena N, Samaratunge R, Härtel CEJ, Eds. Managing with humor; a novel approach to building positive employee emotions and psychological resources. Singapore: Springer, Singapore 2019:141-153.

49. Safavi M, Abdollahi SM, Salmani MM, Rahimi H, Nasirizade M. Relationship between nurses' quality performance and their job satisfaction. J Nurs Manag 2017; 6:53-61. 